\title{
MENINGKATKAN HASIL BELAJAR MATEMATIKA MATERI POKOK PENJUMLAHAN DAN PENGURANGAN DENGAN PENGGUNAAN METODE DEMONSTRASI PADA SISWA KELAS I SD NEGERI O8 SALIMPAUNG
}

\begin{abstract}
Abstrak
Perkembangan kognitif anak usia sekolah dasar berada dalam tahap operasi konkrit, untuk itu pembelajaran di sekolah hendaknya mampu menjembatani siswa dalam memperoleh ilmu pengetahuan yang abstrak melalui benda-benda konkrit. Rendahnya kemampuan dan hasil belajar siswa kelas I SD Negeri 08 Salimpaung dalam operasi penjumlahan dan pengurangan menjadi latar belakang penelitian ini. Jenis penelitian ini adalah penelitian tindakan kelas (PTK) yang dilaksanakan dala dua siklus. Setiap sikus terdiri dari dua pertemuan. Subjek dalam penelitian ini adalah siswa kelas I yang berjumlah 19 orang, dengan siswa laki-laki 11 orang dan siswa perempuan 8 orang tahun ajaran 2017/2018. Teknik pengumpulan data berupa observasi, dokumentasi dan tes. Hasil penelitian ini dapat disimpulkan bahwa metode demonstrasi dengan menggunakan benda konkrit dapat meningkatkan hasil belajar pada materi pokok penjumlahan dan pengurangan siswa kelas I SD Negeri 08 Salimpaung. Pada siklus I hasil ketuntasan belajar pada materi penjumlahan dan pengurangan berada pada persentase $52.53 \%$ dan peningkatan pada siklus II dengan persentase $84.21 \%$.
\end{abstract}

Kata Kunci: Metode Demonstrasi, Hasil Belajar, Penjumlahan dan Pengurangan.

\begin{abstract}
The cognitive development of elementary school age children is in the concrete operation stage, for that learning in schools should be able to bridge students in obtaining abstract knowledge through concrete objects. The low ability and learning result of grade I SD Negeri 08 Salimpaung in addition and subtraction operations are the background of this research. This type of research is a classroom action research (PTK) which is carried out in two cycles. Each cycle consists of two meetings. The subjects in this study were 19 students of grade I, with 11 male students and 8 female students in 2017/2018 school year. Data collection techniques in the form of observation, documentation and tests. The results of this study can be concluded that the demonstration method using concrete objects can improve learning results on the subject matter of addition and subtraction of the grade I students of SD Negeri 08 Salimpaung. In the first cycle the learning resut on addition and subtraction material belong twith a percentage of 52.35\% and in Cycle II with a percentage of $84.21 \%$
\end{abstract}

Keywords: Demonstration method, learning results, addition and subtraction.

\footnotetext{
${ }^{1}$ Guru Sekolah Dasar Negeri 03 Salimpaung, Tanah Datar, Sumatera Barat Alamat email mailiarni81217@gmail.com
} 


\section{PENDAHULUAN}

Matematika merupakan salah satu cabang ilmu pengetahuan yang memegang peranan penting dalam dunia pendidikan. Matematika sebagai ratu ilmu pengetahuan dijadikan penunjang berbagai ilmu pengetahuan, meningkatkan kemampuan dan keterampilan intelektual. Menurut Risnawati (2008) menyatakan bahwa "Matematika perlu diajarkan kepada peserta didik karena selalu digunakan dalam segala segi kehidupan, semua bidang studi memerlukan keterampilan matematika yang sesuai, merupakan sarana komunikasi yang kuat, singkat dan jelas". Melihat pentingnya matematika, maka pelajaran matematika diajarkan dari jenjang sekolah dasar hingga perguruan tinggi (Sarumaha, Harefa, \& Zagoto, 2018).

Kegiatan pembelajaran disekolah mengacu pada kurikulum yang berlaku dengan tujuan pembelajran yang telah ditetapkan dan diharapkan tecapai oleh siswa termasuk dalam pembelajaran matematika. Pembelajaran matematika di sekolah dasar menjadi suatu hal pokok yang sangat diperlukan untuk pembelajaran pada jejang berikutnya (Zagoto, \& Dakhi, 2018). Hal ini dikarenakan matematika suatu pembelajran yang diajarkan secara berkesinambungan dan berkaitan satu sama lain. Untuk itu dalam pembelajaran matematika siswa sekolah dasar harus benar-benar paham dan mengerti setiap pembelajaran yang diajarkan.

Permasalahan yang sering muncul dan sering ditanyakan guru-guru adalah bagaimana pembelajaran matematika yang menyenangkan bagi siswa sekolah dasar sehingga konsep dan tujuan pembelajaran itu dapat tercapai. Selama ini matematika menjadi suatu momok yang menakutkan oleh siswa karena matematika sulit dipahami dan menjenuhkan oleh mereka, akibatnya berdampak pada hasil belajar yang tidak maksimal (Zagoto, 2018). Menurut Piaget pada tahap perkembangan kognitif anak berusia 7-12 tahun berada pada tahap operasional konkrit. Pada tahap ini anak megembangkan konsep dengan menggunakan benda-benda konkrit untuk menyelidiki hubungan dengan model-model abstrak.

Hal senada juga di ungkapkan Tedjasaputra (2001) anak kecil belum mampu berfikir abstrak, karena bagi mereka makna (meaning) dan objek berbaur menjadi satu sehingga mereka tidak mampu membayangkan suatu benda yang disimbolkan dengan benda lain. Dalam pembelajaran matematika yang abstrak, siswa memerlukan alat bantu berupa media dan peraga yang dapat memperjelas apa yang akan disampaikan oleh guru, sehingga materi yang dipelajari akan lebih cepat dipahami dan dimengerti oleh siswa (Heruman, 2008). Benda- benda konkrit dalam pembelajaran matematika kelas I dapat berupa benda-benda yang mereka kenali dan memudahkan mereka dalam menggukannya misalnya : lidi,batu dan lainnya.

Berdasarkan temuan di lapangan diperoleh informasi bahwa siswa kelas I SD Negeri 08 Salimpaung pada pokok bahasan penjumlahan dan pengurangan masih rendah, hal ini diketahui dari nilai hasil ulangan harian siswa yang masih banyak di bawah KKM. Dari 23 orang siswa hanya $40 \%$ siswa yang memeperoleh nilai di atas KKM. Hal ini disebabkan oleh beberapa faktor yaitu Siswa masih terbawa suasana belajar pada Taman Kanak-Kanak sehingga dalam pembelajaran siswa tidak memiliki konsentrasi penuh, Guru kurang tepat dalam menggunakan metode dan belum menggunakan alat-alat konkrit dalam pembelajaran.

Berpijak dari permasalahan yang ada di lapangan diperlukan suatu perbaikan dalam pembelajaran untuk dapat meningkatkan hasil belajar siswa dalam pembelajran matematika. Banyak cara yang dapat digunakan salah satu nya dengan menggunakan metode pembelajaran. Metode demonstrasi adalah suatu metode pembelajaran cara penyajian pembelajaran dengan memperagakan dan mempertunjukkan kepada siswa tentang suatu proses, situasi, atau benda tertentu yang sedang dipelajari baik dalam bentuk sebenarnya maupun dalam bentuk tiruan yang dipertunjukkan oleh guru atau sumber belajar lain yang ahli dalam topik bahasan yang harus didemonstrasikan (Sumantri dalam Abi, 2009; Zagoto, Yarni \& Dakhi, 2019). Sedangkan menurut Daryanto (2009) metode demonstrasi merupakan suatu cara penyajian informasi dalam proses belajar mengajar dengan mempertunjukan tentang cara melakukan sesuatu disertai dengan penjelasan secara Visual dari proses yang jelas.

Metode demontrasi adalah cara penyajian pelajaran dengan memperagakan dan mempertunjukan kepada siswa tentang suatu proses, situasi atau benda tertentu yang sedang dipelajari baik dalam bentuk sebenernya maupun dalam bentuk tiruan. Keunggulan metode 
demonstarsi diantaranya adalah kemungkinan siswa mendapat kesalahan lebih kecil, sebab siswa mendapatkan langsung dari hasil pengamatan kemudian siswa memperoleh pengalaman langsung, siswa dapat memusatkan perhatiannya pada hal-hal yang dianggap penting, bila melihat hal-hal yang membuat keraguan, siswa dapat bertanya langsung pada guru (Ismail, Mudjiran \& Neviyarni, 2019) . Oleh sebab itu, pada penelitian ini digunakan metode demonstrasi menggunakan benda-benda konkrit pada pokok bahasan penjumlahan dan pengurangan.

Langkah-langkah metode demonstrasi yang digunakan mengacu pada langkah-langkah yang dikemukan oleh Yamin (2013) yang terdiri dari tiga tahapan yaitu: Tahap Persiapan Demonstarsi meliputi merumuskan tujuan pembelajaran yang dicapai setelah demonstarsi, Tahap Pelaksanaan meliputi diawali pengaturan tempat duduk siswa, memyampaika tujuan pembelajaran hingga memberikan kesempatan pada siswa untuk daktif dalam kegiatan demonstrasi yang dilakukan, dan Tahap Mengakhiri Demonstarsi meliputi pemberian tugas terkait materi yang dipelajari dan siswa diberikan kesempatan untuk melakukan latihan keterampilan seperti yang diperagakan guru.

\section{METODE}

Metode penelitian ini adalah Penelitian Tindakan Kelas (PTK). Menurut Arikunto (2014:58), Penelitian Tindakan Kelas adalah penelitian tindakan yang dilakukan dikelas dengan tujuan memperbaiki atau meningkatkan mutu praktik pembelajaran. Karakteristik yang khas dalam penelitian ini yakni adanya tindakan-tindakan yang berulang (siklus) untuk memperbaiki proses belajar mengajar di kelas. Penelitian ini dilaksakan dalam dua siklus dimana masingmasing siklus dilakukan dua pertemuan. Jika pada siklus I terdapat hambatan atau permasalahan pada pembelajaran maka akan dilakukan siklus II dan dilakukan perbaikan pada hambatan atau permasalahan yang ada pada sikulus I.

Subjek penelitian ini adalah siswa kelas I SD Negeri 08 Salimpaung dengan jumlah siswa 19 orang terdiri dari 11 siswa laki-laki dan 8 siswa perempuan. Teknik pengumpulan data yang digunakan yaitu Observasi, dokumentasi dan tes. Instrumen penelitian dalam penelitian ini adalah lembar observasidan soal tes. Tes yang diberikan berkaitan dengan materi penjumlahan dan pengurangan disesuaikan dengan KD dan indikator pembelajaran. Lembar observasi yang digunakan yakni lembar observasi guru dan lembar observasi siswa. Dokumentasi berupa fotofoto dalam proses pembelajaran.

Jenis data yang diperoleh pada penelitian ini adalah data kuantitatif dan data kualitatif yang dipeoleh dari tes hasil belajar, lebar observasi guru dan siswa. Teknik analisis data merupakan analisis statistik deskriptif yang digunakan untuk mengetahui nilai rata-rata dan persetase hasil belajar yang dicapai siswa apakah ada peningkatan atau tidak. Indikator kinerja dalam penelitian ini dilihat dari dua segi yaitu segi proses dan segi hasil. Dari segi proses tindakan pembelajaran dikatakan berhasil apabila $90 \%$ skenario pembelajaran terlaksana dengan baik, sedangkan dari segi hasil belajar tindakan dikatakan berhasil apabila $80 \%$ siswa telah memperoleh nilai diatas KKM 70.

\section{HASIL DAN PEMBAHASAN}

Penelitian tindakan kelas diawali tahap perencanaan siklus I, dimulai dari merancang RPP hingga merancang soal tes yang akn diujikan pada akhir siklus I. Kegiatan guru dan siswa disetiap pertemuan dinilai, kegiatan guru dinilai observer dan siswa dinilai oleh guru yang mengajar. Materi pada siklus I yaitu penjumlahan dan pengurangan bilangan cacah sampai 50. Pembelajaran berlansung menggunakan langkah-langkah metode demonstrasi, demonatrasi yang dilakukan dengan menggunakan benda konkrit yaitu lidi.

Masing-masing siswa diberikan lidi untuk berhitung yang mana sebelumnya guru melakukan demonstarsi didepan kelas. Namun pada saat demonstrasi ada beberapa siswa yang masih belum fokus, hal ini di akibatkan mereka masih asyik keluar masuk kelas. Ada pula siswa yang belum paham dalam mengerjakan latihan tapi enggan untuk bertanya. Berdasarkan 
pantauan observer masih perlu dilakukan perbaikan dari guru dalam melaksanakan pembelajaran serta bagaimana guru juga melibatkan siswa aktif dalam belajar.

Setelah siklus I dilaksanakan sebnyak dua pertemuan, maka tahap berikutnya adalah melakukan tes. Soal tes telah disediakan yang disesuaikan dengan KD, Indikator dan tujuan pembelajaran. Berdasarkan tes yang dilakukan menunjukan bahwa dari 19 orang siswa kelas I SD Negeri 08 Salimpaung sebanyak 10 siswa memperoleh nilai di atas KKM dengan persentase ketuntasan $52.63 \%$ sedangkan siswa yang tidak tuntas ada 9 orang dengan pesentase ketidaktuntasan $47.37 \%$. Hasil ini cukup baik namuan belum memenuhi kriteria ketuntasan secara klasikal yakni $80 \%$. Oleh karena itu dilakukan refleksi terhadap siklus I, kemudian dilakukan perbaikan rancangan pembelajaran dan diterapkan pada siklus II.

Kegiatan siklus II diharapkan lebih baik dari siklus I. Pada siklus II guru tetap dinilai dengan lembar observer dan kegiatan siswa juga dinilai oleh guru. Materi yang diajarkan pada siklus II yakni penjumlahan dan pengurangan bilangan cacah sampai 100. Metode yang digunakan tetap metode demonstrasi. Kegiatan awal diawali dengan mengatur tempat duduk siswa, guru melakukan apersepsi, menyampaikan tujuan pembelajaran.

Guru juga memberikan 100 lidi pada masing-masing siswa yang akan di gunakan siswa nanti dalam proses pembelajaran. Guru melakukan demonstrasi yang diperhatikan oleh siswa, kali ini perhatian siswa sudah terfokus pada demonstarsi yang diperlihatkan guru. Pembelajaran menjadi semakin asyik saat para siswa mulai percaya diri dalam bertanya serta ikut terlibat dalam melakukan demonstarasi bersama guru. Pada proses pengerjaan latihan guru sudah melakukan pengawasan secara meyeluruh dan dengan tanggap memberikan bantuan pada siswa yang mengalami kesulitan dalam menyelesaikan soal. Dilihat dari pelaksanaannya pada siklus II guru dan siswa sudah melakukan kegiatan pembelajaran yang semakian baik.

Setelah siklus II dilakukan siswa juga diberikan tes untuk melihat bagaimana perkembangan hasil belajar mereka. Berdasarkan hasil tes menunjukan bahwa kemampuan siswa dalam menyelesaikan soal-soal penjumlahan dan pengurangan sudah lebih baik dari siklus I dan Pra siklus. Hal ini terbukti dengan 16 siswa memiliki nilai di atas KKM dengan persentase ketuntasan adalah $84.21 \%$ dan hanya 3 siswa yang masih beleum tuntas dengan persentase $15.79 \%$. Hasil tersebut menunjukan bahwa pencapaian ketuntasan belajar siswa sudah melebihi ketuntasan klasikal yakni $84.21 \%$.

Persentase peningkatan ketuntasan belajar siswa sebelum pengunaan metode demonstrasi, siklus I dan siklus II dapat dilihat pada grafik berikut:

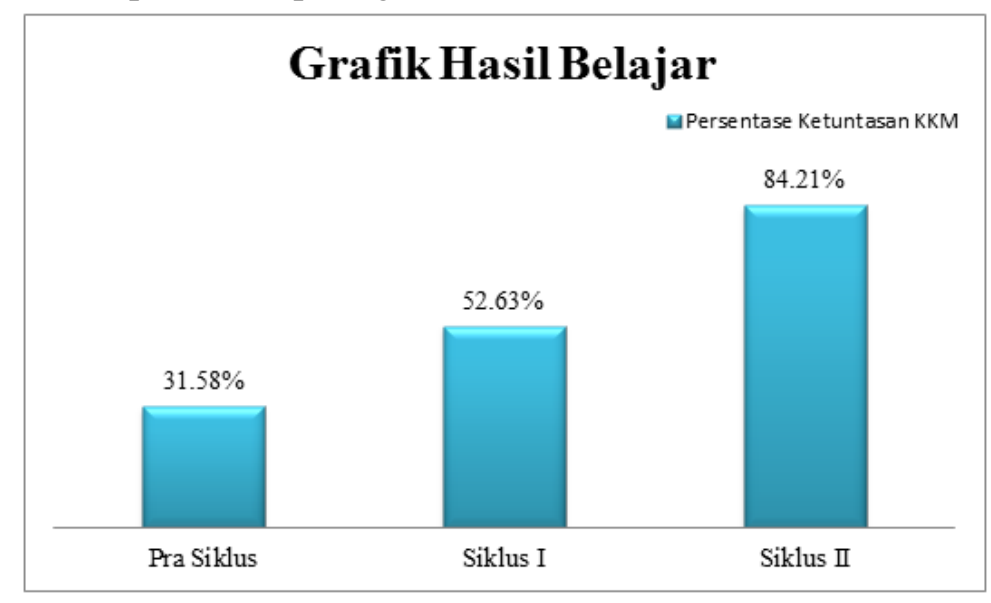

Berdasarkan grafik hasil belajar siswa pada materi penjumlahan dan pengurangan dapat dilihat pra siklus ketuntasan hanya $31.58 \%$, kemudian setelah dilakukan Siklus I ketuntasan hasil belajar meningkat menjadi $52.63 \%$. pada siklus II hasil belajar siswa juga mengalami peningkatan yang cukup signifikan yakni menjadi $84.21 \%$. Hal ini menunjukan bahwa dengan metode demonstrasi pada materi penjumlahan dan pengurangan memberikan peningkatan hasil belajar pada siswa kelas I SD Negeri 08 Salimpaung. 


\section{SIMPULAN}

Berdasarkan hasil penelitian tindakan kelas terhadap hasil belajar siswa kelas I SD Negeri 08 Salimpaung dengan menggunakan metode demonstrasi pada materi penjumlahan dan pengurangan menunjukan adanya peningkatan hasil belajar yang semakin membaik dari siklus I hingga siklus II. Secara klasikal pengusaan materi dari hasil tes siklus I 52.63\% meningkat sejauh $21,05 \%$ dari tahap pra siklus. Hasil belajar pada siklus II $84.21 \%$ dan meningat sejauh $31.58 \%$. Hal ini menunjukkan bahwa bahsa hasil belajar siswa sudah membaik dan sudah melewati kriteria ketuntasan yakni $80 \%$ siswa yang melewati KKM. Dari aspek kegiatan pembelajaran terlihat bahwa siswa lebih mudah memahami konsep dengan tahap-tahapan demonstrasi dan benda konkrit yang digunakan.

\section{DAFTAR PUSTAKA}

Abi Manyu, Soli (2009). Strategi Pembelajaran. Jakarta: Depdiknas.

Arikunto, Suharsimi (2014). Penelitian Tindakan Kelas. Jakarta: Bumi Aksara

Daryanto (2009). Evaluasi Pendidikan. Jakarta : PT Rineka Cipta

Heruman (2008). Model Pembelajaran Matematika Di Sekolah Dasar. Bandung: Remaja Rosdakarya

Rafki Nasuha Ismail, Mudjiran, Neviyarni (2019). Membangun Karakter Melalui Implementasi Teori Belajar Behavioristik Pembelajaran Matematika Berbasis Kecakapan Abad 21. MENARA Ilmu, Vol 13, No 11 DOI: https://doi.org/10.31869/mi.v13i11.1649

Risnawati (2008). Strategi Pembelajaran Matematika. Pekanbaru: Suska Press.

Sarumaha, R., Harefa, D., \& Zagoto, M.M. (2018). Upaya Meningkatkan Kemampuan Pemahaman Konsep geometri Transformasi Refleksi Siswa Kelas XII-IPA-B SMA Kampus Telukdalam Melalui Model Pembelajaran Discovery learning Berbantuan Media Kertas Milimeter. Jurnal Education and development, 6 (1); 90-96. Institut Pendidikan Tapanuli Selatan.

Tedjasaputra, Mayke S (2001). Bermain, Mainan, dan Permainan. Jakarta : Grasindo

Yamin, M (2013), Strategi Dan Metode Dalam Model Pembelajaran, GP Press Group, Jakarta

Zagoto, Maria M., Nevi Yarni \& Dakhi, O (2019). Perbedaan Individu dari Gaya Belajarnya Serta Implikasinya Dalam Pembelajaran. Jurnal Review Pendidikan dan Pengajaran, 2(2), 259-265.

Zagoto, Maria M. \& Dakhi, O (2018). Pengembangan Perangkat Pembelajaran Matematika Peminatan Berbasis Pendekatan Saintifik Untuk Siswa Kelas XI Sekolah Menengah Atas. Jurnal Review Pendidikan dan Pengajaran, 1(1), 157-170.

Zagoto, Maria M. (2018). Pengembangan Perangkat Pembelajaran Matematika Berbasis Realistic Mathematic Educations Untuk Siswa Kelas V Sekolah Dasar, Jurnal Education And Development, vol. 3, no. 1, p. 53, Feb. 2018. 